\title{
The Impact of Audiovisual Media Towards Ability on Counting, Measurement, and Geometric
}

\author{
${ }^{1}$ Rendy Setyowahyudi, ${ }^{2}$ Slamet Suyanto \\ ${ }^{1}$ rendy.setyowahyudi@yahoo.co.id, ${ }^{2}$ slamet_suyanto@uny.ac.id \\ ${ }^{1,2}$ Graduate Program of Yogyakarta State University Yogyakarta, Indonesia
}

\begin{abstract}
The aim of this study is to knowing the impact and differences of audiovisual media and conventional media toward the ability on (1) counting, (2) measurement and (3) geometric for children agile 4-5-year-old. The method used in this study is experimental methods with quasi experimental design. The subject of this study are children in agile 4-5year-old in Rahmatullah Kindergarten, Banyuwangi City, Indonesia which are 84 children in total from middle-up background of family. The authors used interview and data collection instrument through audiovisual media. Technique of analysis of this study consist of data prerequisites test and data hypothesis test. The data test prerequisites consist of normality, homogeneity, and linearity test. While data hypothesis test uses analysis covariance with $5 \%$ of significance level. According to the result on data hypothesis test on ability of counting, measurement, and geometric shows sig analysis covariance variable at $0,000<0,05$. Therefore we can conclude that there is impact and differences on the using of audiovisual media and conventional media toward ability on (1) counting, (2) measurement, and (3) geometric for children agile 4-5-year-old.
\end{abstract}

Keywords: Audiovisual Media; Ability of Counting; Measurement; Geometric.

\section{Introduction}

Mathematics ability which includes the ability to count, measurement, and geometric determine the successful of children on all subjects in their early year of school[1]. It is important to develop children's ability to count in early age since it is the basic of mathematic achievements in the next stages[2]. Another benefit of developing child's ability to count is it can also improve their cognitive and mathematic skills[3]. Furthermore, there is statement saying that early age children who already have strong basic ability to count tend to get good academic achievements in the future[4]. Besides the ability to count, ability on measurement and geometric are also important parts to be developed in early age.

Ability on measurement is important to be developed in early age children to teach them how to measurement in a right way, using proper mathematic language, and to solve simple measurement problems[5]. Meanwhile, ability on geometric is important to be developed as well due to the fact that geometric knowledge allows children to have skills that they need, advance knowledge on science, technology, and mathematics[6]. Moreover, whenever children are being taught on geometric therefore their visual, verbal, drawing, and logical ability would also improved[7]. Stimulating ability to count, measurement, and geometric can be done through fun media. One of the alternative media that can stimulate those kinds of abilities is audiovisual media. The definition of audiovisual media is audio and visual combination or can be called the media view and hear[8].

Audiovisual media are already implemented in many schools and result better score in student's knowledge and academic achievement, yet the academic achievement in this term are ability on counting, measurement, and geometric. Problem based on our preliminary 
observation is that teachers in Rahmatullah Kindergarten have applied several media but not implement it optimally yet to develop children's ability on counting, measurement, and geometric.Therefore, it makes student's ability on count, measurement, and geometric is quite low. According to aforementioned problems, so that audiovisual media would be tested to know the impact and differences compare to conventional media toward children's ability to count, measurement, and geometric in agile 4-5-year-old in Rahmatullah Kindergarten, Banyuwangi City, Indonesia.

\section{Related Works/Literature Review}

To be able to convey a good message or learning material, the right media is needed. One type of media that can be used is audiovisual media. At present, more information and communication technology in the form of audiovisual media is the center of community progress in developing skills and abilities [9]. The consumption of audiovisual media is an indisputable fact at this time, audiovisual media has become very important for today's society because it is a communicator of information and communication in everyday life[10]. Audiovisual media itself has the understanding that the media has elements of sound and elements of images that can be seen[11].

In kindergarten (TK) age there are many children show their mathematical skills include the ability to count[12]. It was told by Runtukahu \& Kandou[13] that counting is a process when children mentioning numbers with its number names. The aim of counting ability is also explained by Coronata \& Alsina[14] that during early age, counting ability is a key to learning further mathematics.

The activiteis related to this measurement aims in order that early age children after being adults are able to measure accurately such as a trader that should be able to weigh goods according to buyer's desire. Measurement is a key component in a mathematic curriculum[15]. Definition of other measurement ability is mentioned by Rasyid[16] that measurement is a process of giving number in a specific characteristic owned by specific individual, things or objects according to clear rules.

Geometry was firstly introduced by ancient Greek philosopher named Thales. Definition of geometry is explained by Thales that geometry is a practical science on length, width and volume with formal mathematical elements[17]. Nowadays, geometry is a study on a twodimentional figure and gemoetry and their connections[13]. The benefits of having knowledge on geometry can be perceived by humans even during baby age, such as what is explained by Haynes on how a baby has been able to develop a geometric thinking geometris during he moves around, learning on space and himself available in a room because they can explore regions through their senses[18].

\section{Methodology}

\subsection{Data}

The technique used in this study is direct interview to the children. Meanwhile for the data collection instrument we used audiovisual media to collect data on their ability on counting, measurement, and geometric. The range of scoring in this study is dichotomy scoring system ( 0 and 1$)$. Score ' 0 ' for children who are not able, and ' 1 ' for those who able. The total score then would be counted by looking at the percentage on each score that they got. The categories of result are 0-20 (very poor), 21-40 (poor), 41-60 (enough), and 61-80 (good), and 81-100 (very good). Before the instrument implemented, we conducted primary validity test by using biserial correlation point and reliability by using KR20 formula.

\subsection{Method}


On this study the authors use experimental method with quasi experiment design to test the audiovisual media toward children's ability on counting, measurement, and geometric. The explanations are as follows:

\subsection{Date and Place of Study}

The study has been conducted in Rahmatullah Kindergarten, Banyuwangi City, Indonesia start from May to June, 2018.

\subsection{Subject of Study}

The subject of this study are children in agile 4-5-year-old in Rahmatullah Kindergarten, Banyuwangi City, which are 84 in total with middle-up background of family.

\subsection{Data Analysis Technique}

Data analysis technique in this study to test the hypothesis is analysis covariance with $5 \%$ of significance level. Before the hypothesis test, we conducted data prerequisite test in normality, homogeneity, and linearity tests. The data then would be analyzed by using SPSS 14.0 for Windows, for the sake of the test we can get these hypothesizes:

Hypothesis 1 : There is impact and difference on the using of audiovisual media and conventional media towards children's ability to count.

Hypothesis 2 : There is impact and difference on the using of audiovisual media and conventional media towards children's ability to measurement.

Hypothesis 3 : There is impact and difference on the using of audiovisual media and conventional media towards children's ability on geometric.

\section{Results and Discussion}

\subsection{Pretest and Posttest Results}

The description of pretest and posttest results in an image of result of study done by the authors. Data collected during the study process are interview results toward children's ability on counting, measurement, and geometric in Rahmatullah Kinderarten, Banyuwangi City. The result then analyzed by using SPSS 14.0 for Windows. The data on interview result is described in the form of pretest and posttest results. Pretest is the result of interview on children's ability towards experimental group and control group before those two groups treated with certain treatments to knowing the child's preliminary ability. While, posttest is result of interview after the experimental group treated with audiovisual media and control group still using conventional media. The following tables will explain more about pretest and posttest result toward children's ability to count, measurement, and geometric.

Table 1. Pretest and posttest data on ability to counting

\begin{tabular}{|l|l|r|r|r|r|}
\hline \multicolumn{2}{|c|}{} & \multicolumn{2}{|c|}{ Pretest } & \multicolumn{2}{|c|}{ Posttest } \\
\cline { 3 - 6 } \multicolumn{2}{|l|}{} & Experiment & Control & Experiment & Control \\
\hline $\mathrm{N}$ & Valid & 42 & 42 & 42 & 42 \\
\hline & Missing & 0 & 0 & 0 & 0 \\
\hline Mean & 40,4286 & 38,7381 & 83,8810 & 43,7857 \\
\hline \multicolumn{2}{|l|}{ Minimum } & 17,00 & 13,00 & 70,00 & 22,00 \\
\hline Maximum & 65,00 & 61,00 & 100,00 & 65,00 \\
\hline Sum & 1698,00 & 1627,00 & 3523,00 & 1839,00 \\
\hline
\end{tabular}

Table 2. Pretest and posttest data on ability to measurement 


\begin{tabular}{|l|l|r|r|r|r|}
\hline \multicolumn{2}{|c|}{} & \multicolumn{2}{|c|}{ Pretest } & \multicolumn{2}{|c|}{ Posttest } \\
\cline { 3 - 6 } \multicolumn{2}{|l|}{} & Experiment & Control & Experiment & Control \\
\hline $\mathrm{N}$ & Valid & 42 & 42 & 42 & 42 \\
\hline & Missing & 0 & 0 & 0 & 0 \\
\hline Mean & 38,6905 & 37,8095 & 84,0952 & 40,8810 \\
\hline Minimum & 22,00 & 22,00 & 67,00 & 28,00 \\
\hline Maximum & 56,00 & 50,00 & 100,00 & 61,00 \\
\hline Sum & 1625,00 & 1588,00 & 3532,00 & 1717,00 \\
\hline
\end{tabular}

Table 3. Pretest and posttest data on ability to geometric

\begin{tabular}{|l|l|r|r|r|r|}
\hline \multicolumn{2}{|c|}{} & \multicolumn{2}{|c|}{ Pretest } & \multicolumn{2}{|c|}{ Posttest } \\
\cline { 3 - 6 } \multicolumn{2}{|l|}{} & Experiment & Control & Experiment & Control \\
\hline N & Valid & 42 & 42 & 42 & 42 \\
\hline & Missing & 0 & 0 & 0 & 0 \\
\hline Mean & 42,9524 & 43,0000 & 86,1905 & 51,3333 \\
\hline Minimum & 21,00 & 29,00 & 64,00 & 29,00 \\
\hline Maximum & 57,00 & 64,00 & 100,00 & 64,00 \\
\hline Sum & 1804,00 & 1806,00 & 3620,00 & 2156,00 \\
\hline
\end{tabular}

\subsection{Result of validity and reliability test}

According to validity test using the biserial correlation point, we know that the valid item will have criteria $>0.3[19]$ on counting, measurement, and geometric items. Validity test of all 26 items on ability to count shows that 23 items declared valid because the value is above 0.3 , while 3 other items are not valid because the value is under 0.3 and the average validity value is 0.55 . Ability on measurement from total 18 items declared all valid since the value is above 0.3 and the average validity value is 0.62 . Geometric items from total 16 items shows that 14 of them are valid and 2 others are not with average value 0.55 .

Meanwhile the reliability test toward the items has been conducted by using KR20 to knowing the level of reliability study instrument items. The result of first reliability test toward 26 items of ability on counting is 0.92 . For 18 items of ability on measurement shows 0.90 . While 16 items on ability on geometric shows 0.84 . According to the aforementioned reliability tests, we can conclude that those variable of instrument are reliable.

It is because the value of reliability instrument on ability to count is 0.92 and $r$ table is 0.361 , therefore the reliability result is $0.92>0.361$ ( $\mathrm{r}$ table). Reliability result on ability to measurement is 0.90 and $r$ table is 0.361 , therefore the reliability result is $0.90>0.361(\mathrm{r}$ table). Meanwhile, the reliability result on ability on geometric is 0.84 and $r$ table is 0.361 , therefore the reliability result is $0.84>0.361$ ( $\mathrm{r}$ table). According to that analysis we can conclude that instrument items on those variables are reliable.

\subsection{Normality test}

The data normality test in this study use Kolmogorov Smirnov Test, in which it will be declared as normal if $p>0.05$. Review on normality test can be seen in the table as follow.

Table 4. Review on normality test 


\begin{tabular}{|c|c|c|c|c|}
\hline Number & Group & Variable & Pretest & Posttest \\
\hline \multirow[t]{3}{*}{1} & \multirow[t]{3}{*}{ Experiment } & Counting & 0,380 & 0,505 \\
\hline & & Measurement & 0,457 & 0,408 \\
\hline & & Geometric & 0,133 & 0,099 \\
\hline \multirow[t]{3}{*}{2} & \multirow[t]{3}{*}{ Control } & Counting & 0,189 & 0,519 \\
\hline & & Measurement & 0,087 & 0,296 \\
\hline & & Geometric & 0,154 & 0,127 \\
\hline
\end{tabular}

According to the table, normality test towards pretest and posttest of those two groups shows that the data is normally distributed, because $p>0.05$. It can be seen on the significance value on each groups. The experimental group gets significance value 0.380 on counting pretest and 0.505 on counting posttest. Meanwhile, the sig value is 0.457 on measurement pretest and 0.408 on measurement posttest. The result shows sig value 0.133 on geometric pretest and 0.099 on geometric posttest. For the control group, the result is 0.189 on counting pretest and 0.519 on the posttest. And the sig value is 0.087 on the measurement pretest and 0.296 for the posttest. And finally the sig value is 0.154 on the geometric pretest and 0.127 for the posttest. Therefore, it can be concluded that both groups are normally distributed.

\subsection{Homogeneity test}

The result of homogeneity test was conducted with Levene Test. The data will be declared as homogeny if $\mathrm{p}>0.05$. Review on result of homogeneity test can be seen at the following table.

Table 5. Review on results of homogeneity test

\begin{tabular}{|l|l|l|}
\hline Number & Variable & Sig Value \\
\hline 1 & Counting & 0,144 \\
\hline 2 & Measurement & 0,066 \\
\hline 3 & Geometric & 0,137 \\
& & \\
\hline
\end{tabular}

According to the table, variable of ability on counting, measurement, and geometric shows significance value of $\mathrm{p}>0.05$. The counting variable gets significance value as 0.144 . Measurement variable gets 0.066 . And geometric variable gets 0.137 . Therefore, it can be concluded that they are similar or homogeny. Since the data are homogeny so that we could conduct ANCOVA test.

\subsection{Linearity test}

Linearity test is a test to know whether or not there is linear relation between pretest and posttest values either on control group or experimental group. If the sig value $>0.05$ so that significance linear relation between pretest and posttest value is exist. Review on the linearity test can be seen at the following table.

Table 6. Review on result of linearity test 


\begin{tabular}{|l|l|l|l|}
\hline Number & Variable & Experiment & Control \\
\hline 1 & Counting & 0,432 & 0,078 \\
\hline 2 & Measurement & 0,079 & 0,430 \\
\hline 3 & Geometric & 0,263 & 0,283 \\
\hline
\end{tabular}

According to aforementioned result of linearity test, we can see that sig $>0.05$ both on experimental group and control group with variables on ability on counting, measurement, and geometric. The result shows that there is linear relation between pretest and posttest value on those three variables.

\subsection{Hypothesis test}

Hypothesis 1 : There is impact and difference on the using of audiovisual media and conventional media towards children's ability to count.

To test the data for Hypothesis 1 we use analysis covariance (ANCOVA) test. The following are the result of analysis covariance test on children's ability on counting.

Table 7. Result of ancova test on counting

\begin{tabular}{|l|l|l|c|}
\hline \multicolumn{2}{|l|}{} & \multicolumn{1}{|c|}{ Value Label } & N \\
\hline Treatment & 1,00 & Audiovisual & 42 \\
\hline & 2,00 & Conventional & 42 \\
\hline
\end{tabular}

Dependent Variable: Counting Posttest

\begin{tabular}{|l|r|r|r|}
\hline \multicolumn{1}{|c|}{ Treatment } & \multicolumn{1}{c|}{ Mean } & Std. Deviation & N \\
\hline Audiovisual & 83,8810 & 9,87533 & 42 \\
\hline Conventional & 43,7857 & 12,11235 & 42 \\
\hline Total & 63,8333 & 22,96505 & 84 \\
\hline
\end{tabular}

Dependent Variable: Counting Posttest

\begin{tabular}{|l|r|r|r|r|r|}
\hline \multicolumn{1}{|c|}{ Source } & \multicolumn{1}{c|}{$\begin{array}{c}\text { Type III } \\
\text { Sum of } \\
\text { Squares }\end{array}$} & Df & $\begin{array}{c}\text { Mean } \\
\text { Square }\end{array}$ & F & Sig. \\
\hline $\begin{array}{l}\text { Corrected } \\
\text { Model }\end{array}$ & $36447,848(\mathrm{a})$ & 2 & 18223,924 & 201,498 &, 000 \\
\hline Intercept & 14543,381 & 1 & 14543,381 & 160,803 &, 000 \\
\hline $\begin{array}{l}\text { Counting } \\
\text { Pretest }\end{array}$ & 2687,658 & 1 & 2687,658 & 29,717 &, 000 \\
\hline Treatment & 32276,373 & 1 & 32276,373 & 356,873 &, 000 \\
\hline Error & 7325,818 & 81 & 90,442 & & \\
\hline Total & 386048,000 & 84 & & & \\
\hline $\begin{array}{l}\text { Corrected } \\
\text { Total }\end{array}$ & 43773,667 & 83 & & & \\
\hline
\end{tabular}

a $\mathrm{R}$ Squared $=, 833$ (Adjusted R Squared $=, 829$ )

According to the table, significance value for Treatment from ANCOVA test is 0.000 , since the value is far under 0.05 so that Hypothesis 1 can be accepted and therefore, 
there is impact and difference on the using of audiovisual media and conventional media toward children's ability on counting. If we look more carefully, the average posttest value of experimental group is higher (83.8810) than average posttest value of control group (43.7857). From this average posttest value, we can conclude that there is difference occur whenever we apply audiovisual media instead of conventional media, whereas the using of audiovisual media is better to improve children's ability on counting.

Hypothesis 2 : There is impact and difference on the using of audiovisual media and conventional media towards children's ability to measurement.

To test the data for Hypothesis 2 we use analysis covariance (ANCOVA) test. The following are the result of analysis covariance test on children's ability on measurement.

Table 8. Result of ancova test on measurement

\begin{tabular}{|l|l|l|r|}
\hline \multicolumn{2}{|l|}{} & \multicolumn{1}{|c|}{ Value Label } & N \\
\hline Treatment & 1,00 & Audiovisual & 42 \\
\hline & 2,00 & Conventional & 42 \\
\hline
\end{tabular}

Dependent Variable: Measurement Posttest

\begin{tabular}{|l|c|r|r|}
\hline Treatment & \multicolumn{1}{|c|}{ Mean } & \multicolumn{1}{|c|}{$\begin{array}{c}\text { Std. } \\
\text { Deviation }\end{array}$} & \multicolumn{1}{c|}{ N } \\
\hline Audiovisual & 84,0952 & 11,81733 & 42 \\
\hline Conventional & 40,8810 & 10,67982 & 42 \\
\hline Total & 62,4881 & 24,45034 & 84 \\
\hline
\end{tabular}

Dependent Variable: Measurement Posttest

\begin{tabular}{|l|r|r|r|c|c|}
\hline \multicolumn{1}{|c|}{ Source } & $\begin{array}{c}\text { Type III } \\
\text { Sum of } \\
\text { Squares }\end{array}$ & Df & $\begin{array}{c}\text { Mean } \\
\text { Square }\end{array}$ & F & Sig. \\
\hline $\begin{array}{l}\text { Corrected } \\
\text { Model }\end{array}$ & $46274,607(\mathrm{a})$ & 2 & 23137,304 & 560,379 &, 000 \\
\hline Intercept & 5915,703 & 1 & 5915,703 & 143,277 &, 000 \\
\hline $\begin{array}{l}\text { Measurement } \\
\text { Pretest }\end{array}$ & 7057,643 & 1 & 7057,643 & 170,934 &, 000 \\
\hline Treatment & 37829,258 & 1 & 37829,258 & 916,214 &, 000 \\
\hline Error & 3344,381 & 81 & 41,289 & & \\
\hline Total & 377619,000 & 84 & & & \\
\hline $\begin{array}{l}\text { Corrected } \\
\text { Total }\end{array}$ & 49618,988 & 83 & & & \\
\hline
\end{tabular}

a R Squared $=, 933$ (Adjusted R Squared $=, 931)$

According to the table, significance value for Treatment from ANCOVA test is 0.000 , since the value is far under 0.05 so that Hypothesis 2 can be accepted and therefore, there is impact and difference on the using of audiovisual media and conventional media toward children's ability on measurement. If we look more carefully, the average posttest value of experimental group is higher (84.0952) than average posttest value of control group (40.8810). From this average posttest value, we can conclude that there is difference occur 
whenever we apply audiovisual media instead of conventional media, whereas the using of audiovisual media is better to improve children's ability on measurement.

Hypothesis 3 : There is impact and difference on the using of audiovisual media and conventional media towards children's ability on geometric.

To test the data for Hypothesis 3 we use analysis covariance (ANCOVA) test. The following are the result of analysis covariance test on children's ability on geometric.

Table 9. Result of ancova test on geometric

\begin{tabular}{|l|l|l|r|}
\hline \multicolumn{2}{|l|}{} & \multicolumn{1}{|c|}{ Value Label } & \multicolumn{1}{c|}{ N } \\
\hline Treatment & 1,00 & Audiovisual & 42 \\
\hline & 2,00 & Conventional & 42 \\
\hline
\end{tabular}

Dependent Variable: Geometric Posttest

\begin{tabular}{|l|c|r|r|}
\hline Treatment & Mean & $\begin{array}{c}\text { Std. } \\
\text { Deviation }\end{array}$ & N \\
\hline Audiovisual & 86,1905 & 10,74820 & 42 \\
\hline Conventional & 51,3333 & 10,51286 & 42 \\
\hline Total & 68,7619 & 20,47133 & 84 \\
\hline
\end{tabular}

Dependent Variable: Geometric Posttest

\begin{tabular}{|l|r|r|r|r|r|}
\hline \multicolumn{1}{|c|}{ Source } & $\begin{array}{c}\text { Type III } \\
\text { Sum of } \\
\text { Squares }\end{array}$ & Df & $\begin{array}{c}\text { Mean } \\
\text { Square }\end{array}$ & F & Sig. \\
\hline $\begin{array}{l}\text { Corrected } \\
\text { Model }\end{array}$ & $26898,708(\mathrm{a})$ & 2 & 13449,354 & 138,169 &, 000 \\
\hline Intercept & 16559,490 & 1 & 16559,490 & 170,120 &, 000 \\
\hline $\begin{array}{l}\text { Geometric } \\
\text { Pretest }\end{array}$ & 1383,279 & 1 & 1383,279 & 14,211 &, 000 \\
\hline Treatment & 25539,659 & 1 & 25539,659 & 262,376 &, 000 \\
\hline Error & 7884,530 & 81 & 97,340 & & \\
\hline Total & 431952,000 & 84 & & & \\
\hline $\begin{array}{l}\text { Corrected } \\
\text { Total }\end{array}$ & 34783,238 & 83 & & & \\
\hline
\end{tabular}

a R Squared $=, 773$ (Adjusted R Squared $=, 768$ )

According to the table, significance value for Treatment from ANCOVA test is 0.000 , since the value is far under 0.05 so that Hypothesis 3 can be accepted and therefore, there is impact and difference on the using of audiovisual media and conventional media toward children's ability on geometric. If we look more carefully, the average posttest value of experimental group is higher (86.1905) than average posttest value of control group (51.3333). From this average posttest value, we can conclude that there is difference occur whenever we apply audiovisual media instead of conventional media, whereas the using of audiovisual media is better to improve children's ability on geometric.

\section{Discussion and Conclusion}


Ability on counting, measurement, and geometric are three aspects that includes in mathematic skills that should be taught and developed to children in early age. As what Morrison[20] said that mathematic topic for each early age class are (a) number and the operations which are counting, presenting, ordering, colliding, and dividing the numbers; (b) geometric which covers drawing shape and room; (c) measurement, including ordering the objects according to measurable attributes. Introducing mathematic for early age child can be done through fun way which is learning media, one of the learning media is audiovisual media.

Results of research and statements from scholars said that audiovisual media could develop children's ability on counting, measurement, and geometric. As a result of research from Pambudi[21] who found results that there was an influence of audiovisual media on children's cognitive abilities in Sragen regency. Furthermore, explained by Spencer[22] that audiovisual media technology can make education more efficient and productive. Meanwhile, Widodo \& Wahyudin[23] explained that good learning media can help children to make abstract mathematics easy.

According to the statements for scholars and result of related studies, it is clear that audiovisual media could improve children's ability on counting, measurement, and geometric. However, those statements and studies never emphasized on the difference between audiovisual media and conventional media. Therefore, in this study the authors try to look at the implication as well as difference on the value or final result of children's ability to count, measurement, and geometric after given treatments such as audiovisual media and conventional media. The result after conducting hypothesis test with analysis covariance method we get sig as $0.000<$ intended level of failure $(\alpha)$ as 0.05 and average value on posttest with audiovisual media treatment as 83.8810 higher than average value with conventional media treatment at 43.7857 .

On the ability to measurement we get the number for sig as $0.000<$ intended level of failure $(\alpha)$ as 0.05 and average posttest value with audiovisual media treatment at 84.0952 higher than average value with conventional media treatment at 40.8810 . As well as the ability on geometric which have the sig at $0.000<$ intended level of failure $(\alpha)$ at 0.05 and average posttest value with audiovisual media treatment at 86.1905 higher than average value with conventional media treatment at 51.3333. Therefore, we can conclude that there is impact and difference on the use of audiovisual media and conventional media toward children's ability on (1) counting, (2) measurement, and (3) geometric in agile 4-5-year-old. But there are still limitations to the study which is expected to be examined by other researchers, namely early childhood math skills are examined in this study are not yet comprehensive, includes 3 new aspects, namely counting, measurement and geometric.

\section{References}

[1] E. Commission, "Math in the Early Year," Prog. Educ. Reform, vol. 14, pp. 1-7, 2013.

[2] E. F. P. K. M. Edens, "An exploratory look at the relationships among math skills, motivational factors and activity choice," Early Child. Educ. J., vol. 41(3), pp. 235243, 2013.

[3] S. F. S. L. Manfra, L. H. Dinehart, "Associations between counting ability in preschool and mathematic performance in first grade among a sample of ethnically diverse, low-income children," J. Res. Child. Educ., vol. 28(1), pp. 101-114, 2014. 
[4] F. J. M. C. Connor, M. Mazzocco, T. Kurz, E. C. Crowe, E. L. Tighe, T. S. Wood, "Using assessment to Individualize Early Mathematics instruction," J. Sch. Psychol., 2017.

[5] J. Z. D. Kotsopoulos, S. Markosz, "Number Knowledge and Young Children's Ability to Measure Length," Early Educ. Dev., 2015.

[6] L. M. D. Zhang, Y. Ding, J. Stegall, "The effect of visual-chunking-representation accommodation on geometry testing for students with math disabilities," Learn. Disabil. Res. Pract., vol. 27(4), pp. 167-177, 2012.

[7] J. Dindyal, "Geometry in the Early Years: a Commentary," ZDM, vol. 47(3), pp. 519$529,2015$.

[8] [8] Hamdani, Media Pembelajaran. Jakarta: PT Raja Grafindo Persada, 2011.

[9] S. V. der G. S. Livingstone, "Media Literacy,” Int. Encycl. Commun., 2008.

[10] P. M. R. A.I. Gómez, "Strategies for media literacy: Audiovisual skills and the citizenship in Andalusia," J. New Approaches Educ. Res. (NAER Journal), vol. 1(1), 2012.

[11] W. Sanjaya, Strategi Pembelajaran Berorientasi Standar Proses Pendidikan. Jakarta: Kencana, 2010.

[12] L. V. H. R. S. Klibanoff, S. C. Levine, J. Huttenlocher, M. Vasilyeva, "Preschool children's Mathematical Knowledge: The Effect of Teacher 'Math Talk," Dev. Psychol., vol. 42(1), p. 59, 2006.

[13] S. K. J. T. Runtukahu, Pembelajaran Matematika Dasar Bagi Anak Berkesulitan Belajar. Yogyakarta: Ar-Ruzz Media, 2014.

[14] A. A. C. Coronata, "Evaluation of the Mathematical Processes in the Practices of Teaching and Learning in Childhood Education," in Procedia-Social and Behavioral Sciences, 2014, pp. 1320-1323.

[15] A. Mac Donald, "Young children's ideas about measurement: What does a kindergarten student consider measuring to be?," Aust. Prim. Math. Classr., vol. 18(1), 2013.

[16] H. Rasyid, Asesmen Perkembangan Anak Usia Dini. Yogyakarta: Multi Presindo, 2009.

[17] Y. U. Widayanti, "No Title," Thales: Tokoh Filsafat Yunani Kuno, 2017. .

[18] M. Conole, "Mathematics in Early Childhood," ACE Pap., no. Issue 16.

[19] Sugiyono, Metode Penelitian Kuantitatif, Kualitatif dan R\&D. Bandung: Alfabeta, 2013.

[20] G. S. Morrison, Dasar-dasar Pendidikan Anak Usia Dini. New Jersey Upper Saddle River: Pearson Education, Inc., 2012.

[21] P. A. Pambudi, "Pengaruh Media Audiovisual Terhadap Perkembangan Kognitif Anak Kelompok B di TK Pertiwi Jenggrik II Sragen Tahun Ajaran 2016/2017,” 2017.

[22] K. Spencer, "Educational Technology: An Unstoppable Force: a Selective Review of Research into the Effectiveness of Educational Media," Educ. Technol. Soc., vol. 2(4), pp. 1-15, 1999.

[23] S. A. Widodo, "Selection of Learning Media Mathematics for Junior School Students," Turkish Online J. Educ. Technol., vol. 17(1), pp. 154-160, 2018. 